Матеріали Всеукраїнської науково-практичної конференції «Актуальні питання діагностики, лікування, раціональної фармакотерапії, диспансеризації та реабілітації в практичі сімейного лікаря"

DOI

\title{
ОСОБЛИВОСТІ ЗМІН ПОКАЗНИКІВ СУДИННО-ТРОМБОЦИТАРНОЇ ЛАНКИ ПЕРВИННОГО ГЕМОСТАЗУ, ФУНКЦІЇ ЕНДОТЕЛІЮ ТА ДЕЯКИХ ЦИТОКІНІВ ЯК МАРКЕРІВ СИСТЕМНОГО ЗАПАЛЕННЯ У ХВОРИХ НА РЕВМАТОЇДНИЙ АРТРИТ У ПЕРІОД КЛІНІКО-ЛАБОРАТОРНОЇ PEMICIÏ
}

\author{
Ю. Г. Бурмак, Ю. М. Казаков, Н. І. Чекаліна, Л. М. Шилкіна, С. І. Треумова, Є. Є. Петров
}

Вищий державний навчальний заклад України «Українська медична стоматологічна академія», м. Полтава

В останній час приділяється значна увага характеру змін маркерів системного запалення у розвитку і прогресуванні патологічних процесів та наголошується на ролі порушень функції ендотелію і особливостях змін первинного гемостазу (ПГ).

Метою роботи була оцінка деяких показників судинно-тромбоцитарної ланки ПГ, вмісту у сироватці крові стабільних метаболітів оксиду азоту (NOx; реактив Гриса), пептиду ендотеліального походження ендотеліну-1 (ЕT-1; імуноферментний метод) та визначення активності сироваткових прозапальних (туморнекротичного фактора альфа - TNF-a, інтерлейкіну (IL) $1 \beta$ - IL-1ß) і протизапального (IL-10) цитокінів (імуноферментний метод) у 21 хворого (віком від 31 до 48 років) на ревматоїдний артрит (РА) у період клініколабораторної ремісії.

Отримані дані свідчили про відсутність змін 3 боку клініко-функціональних тестів судиннотромбоцитарної ланки ПГ та вмісту тромбоцитів, проте показник індукованої ристоміцином агрегації тромбоцитів (IPAT; спектрофотометричний метод) у хворих на РА перевищував значення референтної норми $(n=21)$ у 1,55 раза $(p<0,001)$, окрім того, мало місце вірогідне підвищення вмісту NOx та ET-1 (у 1,22 (p<0,01) та 1,31 раза $(p<0,001)$ відповідно). Означені зміни у показниках тканинної складової ПГ та вмісту метаболітів нітроксиду та ендотеліну-1 у хворих на РА супроводжувались підвищеним, порівняно з референтною нормою, вмістом у крові прозапальних цитокінів - TNF-a (у 1,59 раза) та IL-1及 - у 1,64 раза ( $p<0,001$ в обох випадках). За наявності таких змін TNF-a та IL-1 $\beta$ співвідношення TNF-a/IL-10 у хворих на PA перевищувало показник референтної норми у 1,38 раза, а IL-1及/IL-10 - у 1,43 раза ( $p<0,001$ в обох випадках).

Таким чином, зсуви у судинно-тромбоцитарній ланці ПГ (IPAT) у хворих на РА в період клініколабораторної ремісії, а також підвищення вмісту у крові стабільних метаболітів нітроксиду, ЕТ-1, прозапальних цитокінів (TNF-a, IL-1ß) та підвищення прозапальної активності сироватки крові (TNF-a/IL-10, IL-1ß/IL-10) слід розглядати як активовані маркери системного запалення. 3 урахуванням означеного вище це може передбачати розробку рекомендацій щодо моніторингу таких хворих задля оптимального їх лікування та ефективної реабілітації на амбулаторному етапі. 